\title{
REINTERPRETASI MASLLAHAH SEBAGAI METODE ISTINBĀT HUKUM ISLAM: Studi Pemikiran Hukum Islam Abū Isḥāq Ibrāhīm al-Shāṭibī
}

\author{
Amin Farih \\ Universitas Islam Negeri (UIN) Walisongo Semarang \\ e-mail:am.farih@gmail.com
}

\begin{abstract}
This article aims to analyze al-Shātibī's thought about mașlahah and its contribution to the renewal of Islamic law. Mașlahah is a method of istinbāt which aims to deprive human difficulties in carrying out their obligations, especially in the field of muamalah. General principles of maslahah that was conceived in al-Qur'an and hadis rise in the doctrine of maquassid al-sharīah. The main purpose is to enforce mașlahah as an essential element for the all purposes of Islamic law. The doctrine of maqāsid al-sharìah asserted that the purpose of the law is one, namely mașlahah or goodness and prosperity of mankind. According to al-Shātibī, mașlahah which formulated the law of Islam must consider the aspects of darüriyyah, häjïyyah and tahsininyyah as a structure consisting of three tiers one of another mutually related. The significance of al-Shātibīs thinking about maslahah mursalah is that this method is a kind of unification and as an alternative over differences of opinion among the scholars on the validity of mașlahah mursalah as a method of Islamic law.
\end{abstract}

[]

Artikel ini bertujuan untuk menganalisis pemikiran al-Shātibī tentang maslahah dan kontribusinya dalam pembaharuan hukum Islam. Mașlahah merupakan metode istinbāt hukum Islam yang bertujuan menghilangkan kesulitan-kesulitan manusia dalam menjalankan kewajibannya, terutama dalam bidang muamalah. Prinsip-prinsip umum kemaslahatan yang dikandung dalam al-Qur'an dan Hadis semuanya bermuara pada doktrin maqāșid al-sharīah yang tujuan utamanya adalah untuk menegakkan mașlahah sebagai unsur esensial bagi tujuan-tujuan hukum Islam. Doktrin maqāșid al-sharīah itu menegaskan bahwa tujuan akhir hukum adalah satu, yaitu mașlaḥah atau kebaikan dan kesejahteraan umat manusia. Menurut al-Shātibī, kemaslahatan yang dirumuskan dalam hukum Islam harus memperhatikan pemeliharaan aspek-aspek ḍarūriyyah, hājïyyah dan tahsiniyyah sebagai suatu struktur yang terdiri atas tiga tingkatan yang satu sama lain saling berhubungan. Signifikansi pemikiran al-Shātibī tentang mașlahah mursalah adalah bahwa metode tersebut merupakan pemersatu dan sebagai alternatif atas perbedaan pendapat ulama tentang berlaku atau tidak berlakunya mașlahah mursalah sebagai metode istinbāt hukum Islam.

Keywords: ijtihad, hukum Islam, maqāṣid al-sharīah, istinbāț, maṣlaḥah 
Amin Farih

\section{Pendahuluan}

Pedoman yang tertulis dalam al-Qur'an merupakan ajaran yang kompleks dan sempurna bagi manusia. Sebagai sumber hukum Islam, al-Qur'an dan Hadis merupakan sekumpulan aturan keagamaan yang mengatur semua aspek perilaku kehidupan manusia, baik yang bersifat individual maupun yang bersifat kolektif. Cakupan yang luas ini sumber al-Qur'an dan Hadis menempati posisi yang sangat penting dalam pandangan umat Islam, karena semua problematika kehidupan umat Islam harus merujuk kepada dasar utama yaitu al-Qur'an dan Hadis sebagaimana sabda Nabi Muhammad yang menjelaskan bahwa Allah menurunkan amanah dalam urat nadi hati seorang manusia. Sedangkan keberadaan al-Qur'an diperintahkan untuk dibaca dan dipelajari karena sebaik-baik perkataan dan petunjuk adalah al-Qur'an yang dibawa oleh Muhammad yang diutus untuk umat seluruh alam yang mempunyai nilai universal, tidak mengenal perbedaan ras, suku bangsa dan menentang terhadap sikap diskriminasi. ${ }^{1}$ Sebagai ajaran yang utama al-Qur'an mempunyai

${ }^{1}$ Abī 'Abdillāh Muhammad ibn Ismā'īl al-Bukhārī, Șahīh al-Bukhārī, Beirut, Libanon: Dār al-Kutub al-'Arabī, 1978), h. 256. Penjelasan ini diterangkan dalam bab al-I'tisāam bi al-Kitāb wa 'l-Sunnah. Dalam bab ini disampaikan empat buah hadis: Pertama, membaca dan belajar al-Qur'an. Kedua, tentang fungsi al-Qur'an sebagai pedoman yang universal. Ketiga, Nabi Muhammad diutus untuk semua umat tidak membedakan suku bangsa dan ras. Keempat, menjelaskan tentang berpegang teguh kepada al-Qur'an yang dibawa Nabi Muhammad. Hadis-hadis tersebut sebagai berikut:

$$
\begin{aligned}
& \text { • حثثنا عليُّ بن عبد الله : حدثنا سفيان قال : سألت الأعمش فقال : عن زيد بن وهب : سمعت حذيفة يقول : حدثنا } \\
& \text { رسول الله صلى الله عليه وسلم : (أنَّ الأمانة نزلت من السماء في جذر قلوب الرجال، ونزل القرآن فقرؤوا القرآن، } \\
& \text { وعلموامن السنَّة). } \\
& \text { • حدثنا آدم بن أبي إياس: حدثنا شعبة : أخبرنا عمرو بن مورَّة : سمعت مُرَّة الممداني يقول: قال عبد الله: إن أحسن }
\end{aligned}
$$

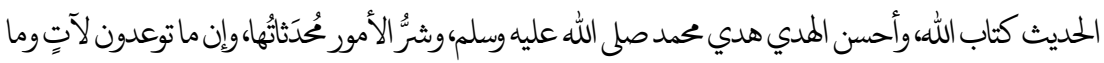

$$
\begin{aligned}
& \text { أنتم بمعجزين. } \\
& \text { • حدثنايهيى بن بكير: حدثنا الليث، عن عُقَيل، عن ابن شهاب : أخبرني أنس بن مالك : أنه سمع عمر، الغد حين } \\
& \text { بايح المسلمون أبا بكر، واستوى على منبر رسول الله صلى الله عليه وسلم، تشَّهَ قبل أبي بكر فقال : أمَّا بعد، فاختار } \\
& \text { الله لرسوله صلى الله عليه وسلم الذي عنده على الذي عندكم، وهذا الكتاب الذي هدى الله به رسولكم، فخذوا } \\
& \text { به تهتدوالماهدى الله به رسوله. }
\end{aligned}
$$

44 || Volume 25, Nomor 1, April 2015 
karakter sifat yang universal (melintasi batas-batas zaman, ras, budaya, adat istiadat dan agama), rasional (akal dan hati nurani sebagai partner dialog) dan i-rasional (yang bersifat wahyu dan ghaib).

Namun demikian dalam perkembangan sejarahnya, keuniversalan alQur'an masih menyisakan beberapa problem metodologis dalam memahaminya sebagai sebuah metode hukum Islam yang progresif. Realitas menunjukkan bahwa respons historis manusia dimana tantangan zaman yang mereka hadapi sangat berbeda dan bervariasi, menjadikan corak dan pemahaman mereka menjadi berbeda pula. ${ }^{2}$ Konteks ini, keberadaan ijtihad menjadi penting dan harus dipublikasikan, dideklarasikan dan digelorakan dikalangan akademisi, ilmuwan, dan cendekiawan Muslim. Dalam konteks menggelorakan ijtihad, ilmu ushul fikih merupakan perangkat metodologi baku yang telah dibuktikan perannya oleh para pemikir Islam seperti imam mazhab dalam menggali hukum Islam. Namun dewasa ini fikih Islam dianggap mandul karena peran kerangka teoritik ilmu ushul fikih dirasa kurang relevan lagi untuk menjawab problem kontemporer. ${ }^{3}$ Oleh karenanya, cukup beralasan jika muncul banyak tawaran metodologi baru dari para pakar hukum Islam kontemporer dalam usaha menggali hukum Islam dari sumber aslinya untuk disesuaikan dengan dinamika kemajuan zaman.

Realitas ini tidak bisa dipungkiri karena fenomena keangkuhan modernitas dan industrialisasi global telah menghegemoni di seluruh lini kehidupan anak manusia sehingga memicu dinamika pemikiran Islam kontemporer dengan segala perangkat-perangkatnya termasuk metodologi ushul fikih (qawā'id ușūliyyah) dan metodologi pemahaman fikih (qawā'id al-fiqhiyyah).

$$
\begin{aligned}
& \text { • حدثنا عبد العزيز بن عبد الله: حدثنا إبراهيم بن سعد، عن ابن شهاب، عن سعيد بن المسيَّب، عن أبي هريرة، أن }
\end{aligned}
$$

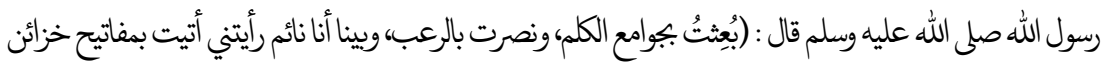

$$
\begin{aligned}
& \text { الأرض فُوضِعت في يدي). }
\end{aligned}
$$

${ }^{2}$ M. Amin Abdullah, Falsafah Kalam di Era Postmodernisme (Yogyakarta: Pustaka Pelajar, 1995), h.227.

${ }^{3}$ Abdullahi Ahmed an-Na'im menjelaskan bahwa ushul fikih sebagai bagian dari perangkat metodologi istinbat hukum Islam formal yang telah teruji eksistensinya untuk memberikan solusi hukum yang secara tekstual belum tercantum dalam al-Qur'an merupakan salah satu solusi alternatif bagian dari keberadaan ijtihad. Lihat: Adullahi Ahmed an-Na'im, Toward an Islamic Reformation: Civil Liberties, Human Rights and International Law (New York: Syracusse University Press, 1990). h. 37. 
Amin Farih

Hal ini merupakan pekerjaan besar yang harus dilakukan dalam rangka membangun citra diri Islam (self image of Islam) di tengah kehidupan modern yang senantiasa berubah dan berkembang. Pada awal sejarahnya, ijtihad yang terformulasikan dalam bentuk metodologi istinbāt hukum Islam (ușūl fiqh) merupakan suatu hal yang digunakan dalam pengertian luas dan mempunyai kekuatan yang dinamis, kreatif tidak statis seperti sekarang ini. ${ }^{4}$ Hal ini dapat dilihat dari munculnya sejumlah mazhab hukum Islam yang memiliki corak sendiri-sendiri, sesuai dengan latar belakang sosio kultural dan kondisi politik dimana mazhab itu tumbuh dan berkembang.

Perspektif pemikiran hukum Islam ulama ushul fikih terkait dengan bisa berubah atau tidaknya hukum Islam melihat dari metode istinbāt hukum Islam apa yang dipakai. Dalam hal ini ulama menerapkan berbagai metode dalam melakukan ijtihad, yakni: qiyās, istiṣlāh, istihsān, maṣlahahah al-mursalah, 'urf, sadd al-dhari'ah. ${ }^{5}$ Untuk menerapkan metode istinbat hukum Islam di atas senantiasa mempertimbangkan atas maqāșid al-sharī'ah ${ }^{6}$ sebagai bagian dari tujuan-tujuan yang hendak dicapai dari suatu penetapan hukum. Kedudukan maqāṣid al-sharīah sangatlah penting, karena menjadi salah satu landasan penetapan hukum, dan menjadi suatu keharusan bagi masalah-masalah yang tidak ditemukan secara tegas dalam naș al-Qur'an dan Hadis, sehingga hukum yang didapatkan tidak akan terlepas dari karakteristik dasar hukum Islam yaitu takammul (sempurna, bulat, tuntas), wasāțiyyah (imbang), dan harākah (dinamis).

Perhatian terhadap maqāṣid al-sharī'ah dalam menentukan hukum Islam sudah muncul pada masa awal Islam. Dalam sebuah hadis, pernah melarang kaum Muslimin menyimpan daging kurban kecuali dalam batas tertentu sekedar perbekalan untuk tiga hari. Namun selang beberapa tahun, ketentuan yang diberikan Nabi Muhammad dilanggar oleh sebagian besar sahabat, kemudian permasalahan ini dikemukakan kepada Nabi Muhammad. Nabi

\footnotetext{
${ }^{4}$ Ahmad Hasan, Pintu Ijtihad Sebelum Tertutup (Bandung: Penerbit Pustaka, 1984), h. 4.

5‘Abd al-Wahhāb Khallāf, Maṣādir al-Tashrī’ fì Mā lā Nașșa fihi (Beirut, Libanon: Dār al Fikr, 1972), h. 67-177.

${ }^{6}$ Makna maqāșid al-sharīah secara etimologis adalah tujuan. Sedangkan secara terminologis adalah kandungan nilai yang menjadi tujuan pensyari'atan hukum. Lihat: Hans Wehr, A Dictionary of Modern Written Arabic (London: Mac Donald and Evans LTD , 1970), h. 767. dan Ahmad al-Hajj alKurdi, al-Madkhal al-Fiqh: al-Qawā'id al-Kulliyah (Damsyiq: Dār al-Ma'arif, 1980), h.186.
} 
membenarkan para sahabat serta menjelaskan bahwa hukum pelanggaran penyimpangan daging kurban itu didasarkan atas kepentingan al-daffah (tamu yang terdiri atas orang-orang miskin yang datang dari perkampungan desa ke kota). Sekarang, kata Nabi, "simpanlah daging-daging kurban itu, karena sudah tidak ada tamu yang membutuhkannya."7

Contoh lain yang populer dalam kaitan ini adalah pendapat sahabat Umar ibn Khattab tentang penghapusan pembagian zakat untuk kelompok muallafatu qulübuhum (orang-orang yang sedang dibujuk hatinya untuk memeluk agama Islam). Kelompok ini pada masa Nabi Muhammad mendapatkan pembagian zakat sesuai ketentuan dalam naș, namun ketika Islam dalam posisi kuat, pelaksanaan zakat dengan tujuan seperti di atas tidak diberlakukan oleh sahabat Umar ibn Khattab. Hal ini karena melihat maqāșid al-sharīah nya, yaitu umat Islam sudah kuat dan tidak perlu bantuan dari orang lain lagi. ${ }^{8}$ Sahabat Umar juga tidak memotong tangan pencuri karena mempertimbangkan tujuan syari'at yang esensi yaitu bahwa latar belakang pencurian tersebut adalah karena kefakiran. Motif pencurian karena tidak tidak mampu makan dan dalam kondisi kelaparan. ${ }^{9}$

\footnotetext{
${ }^{7}$ Malik ibn Anas, al-Muwatța' (Beirut, Libanon: Dār al-Fikr, 1978), h. 299.

8Peristiwa ini terjadi ketika suatu saat Umar ibn Khattab di datangi oleh Uyainah ibn Hashan dan Aqra' ibn Habas. Mereka datang meminta bagian zakatnya sebagimana bagian yang selama ini diterimanya sejak zaman nabi Muhammad. Ketika Umar dimintai fatwa tersebut spontan Umar ibn Khattab berkata: "Sesungguhnya Allah telah menguatkan Islam dan tidak memerlukan kalian lagi, maka kalian masuk Islam masuk Islamlah, dan jika tidak, maka antara kami dan kalian adalah pedang/perang" Terhadap ijtihad Umar ibn Khattab ini tidak seorang sahabatpun menentangnya pada saat itu, dikarenakan tujuan dari Umar ibn Khattab adalah untuk menolak kemungkinan datangnya kejahatan dari mereka setelah Islam dirasa telah kuat dan dakwah dengan cara itu dipandang sudah tidak diperlukan lagi. Lihat: Ahmad Amin, Fajar al-Islam, cet. X (Kotabaru, Pinang, Singapura: Sulaiman Mar'iy, 1965) h. 238. Adapun golongan yang masuk "muallafatu qulūbuhum" pada masa nabi Muhammad adalah Abu Sufyan, Aqra' ibn Habas, Abbas ibn Muradas, Shafwan ibn Umayyah dan Uyainah ibn Hashan.Shafwan pernah berkata : "Muhammad memberiku zakat padahal ia orang yang sangat membenciku karena kekafiranku dan ia terus memberi zakat kepadaku sampai ia menjadi sayang kepadaku karena ke-Islamanku". Lihat: Atho Mudzhar, Membaca Gelombang Ijtihad: Antara Tradisi dan Liberasi (Yogyakarta: Titian Ilahi Press, 1998).h. 41.

${ }^{9}$ Pencurian ini dilakukan oleh Alamah al-Hatib ibn Abi Baltaah. Pada suatu hari dia datang kepada Umar ibn Khattab dan Alamah al-Hatib mengakui perbuatannya. Umar pun segera memerintahkan agar kepadanya dilakukan hukuman potong tangan. Pada waktu itu musim kelaparan. Ketika hukuman akan segera dijalankan, tiba-tiba Umar ibn Khattab melarangnya sambil mengatakan bahwa seandainya ia tidak tahu bahwa orang itu melakukan pencurian karena kelaparan niscaya akan ia potong tangannya. Kemudian Alamah al-Hatib ibn Abi Baltaah (pencuri) segera dibebaskan
} 
Amin Farih

Sahabat Umar juga tidak membagikan harta ghanimah kepada para prajurit perang karena pertimbangan aspek kemaslahatan pada bangsa dan negara, yaitu bahwa kekayaan ghanimah tersebut digunakan untuk membayar pensiunan prajurit dan berbagai kemaslahatan umum. Ghanimah dimasukkan pada bayt al-māl (perbankan Islam). ${ }^{10}$ Masih banyak lagi contoh-contoh pertimbangan ijtihad Umar yang seakan-akan bertentangan dengan zāhir al-naș (al-Qur'an dan Hadis), padahal semestinya bila diteliti secara bijaksana tindakan Umar tersebut sangat memperhatikan tujuan syari'ah (maqāṣid alsharïah). ${ }^{11}$

Perkembangan dan perhatian terhadap maqāṣid al-sharī'ah sebagai pertimbangan dalam melakukan ijtihad inilah yang dikembangkan oleh Imam alShātibì $(790$ H). Hal ini bukanlah hal yang baru, melainkan sudah dilakukan oleh ulama terdahulu. Imam Syafi'i (150 - 204 H) dalam karyanya, al-Risālah, berpendapat bahwa jalan pendekatan pemahaman lewat meneliti dan menganalisa 'illat secara tepat dan benar merupakan cara memahami tujuan nas (maqāṣid al-sharīah). Demikian juga Imam al-Juwaini dalam kitabnya alBurhān, Imam al-Ghazali (445-505 H) dalam kitabnya al-Muștasfā, dan Abu Hasan al-Bisri dalam karyanya al-Mu'tamad.

Metode istiṣlāh (pemahaman maqāṣid al-sharīah yang bertumpu pada prinsip mașlahah) merupakan upaya-upaya pemahaman terhadap kemaslahatan yang tidak dapat dikembalikan secara langsung kepada al-Qur'an dan Hadis, tetapi melalui analisis-analisis kemaslahatan secara umum yang sudah terkandung dalam naș sejak dahulu kala. Metode istișlāh diaplikasikan melalui

dari hukuman potong tangan atas dasar ijtihad Umar ibn Khattab (Baca: Ibnu al-Qayyim alJawziyyah, I'lām al-Muwaqqi'inn 'an Rabb al-'Ālamīn, Juz III (Mesir: Idārah Țibā’ah Mișriyyah, t.th), h. 37.

${ }^{10}$ Sebagaimana ketentuan dalam al-Qur'an (8:41), bahwa 1/5 dari harta rampasan perang haruslah dibagi kepada enam kelompok, yaitu Allah, Rasulullah, kerabat Rasul, anak-anak yatim, orangorang miskin dan ibn sabil. Mafhüm ayat ini, selebihnya 4/5 dibagikan diantara para tentara yang ikut perang. Atas dasar ayat ini maka para tentara yang ikut berperang datang kepada Umar ibn Khattab dan meminta agar harta rampasan perang Irak dan Syam 1/5 daripadanya segera dikeluarkan untuk komponen yang tersebut dalam ayat al-Qur'an dan selebihnya dibagikan kepada tentara yang ikut berperang di Irak dan Syam. Dalam sebuah riwayat, Sa’ad ibn Abī Waqqās yang menjadi pimpinan perang Irak dan Syam menulis surat kepada Umar ibn Khattab untuk segera membagikan ghanimah tersebut kepada prajurit-prajuritnya. Lihat: Bāhī al-Khawlī, "Min Fiqh 'Umar fi al-Iqtișād wa "l-Mal", dalam Majalah al-Muslimin, Vol. IV, Kairo: 1954, h. 56.

${ }^{11}$ Aḥmad al-Ḥajj al-Kurdi, al-Madkhal al-Fiqh: al-Qawā'id al-Kulliyah (Damsyiq: Dār al-Ma'ārif, 1980. h.108. 
mașlahah mursalah. Bagi al-Shāțibī urgensi maṣlahah ini dapat digali dari penajaman analisis terhadap pemahaman tentang maqūșid al-sharīah, karena dalam prespektif sejarah kemaslahatan selalu dikedepankan dalam pembentukan hukum. Al-Shāțibī sendiri telah memberikan porsi yang sangat banyak terhadap mașlaḥah dalam istinbāt hukum Islam. Karya monumentalnya al-I'tișām dan al-Muwāfaqāt menerangkan bahwasanya "kemaslahatan merupakan tujuan diturunkannya wahyu Ilahi guna mengatur kebutuhan hidup manusia" Salah satu kontribusi pemikirannya adalah dengan mencontohkan sepuluh kasus yang berdasarkan mașlaḥah mursalah ${ }^{12}$ yang semua tidak diterangkan secara jelas dan rinci dalam al-Qur'an. Tulisan ini bermaksud menelaah lebih mendalam tentang konsep maslahat al-Shātibī dan kontribusinya dalam pemikiran pembaruan Hukum Islam.

\section{Definisi Mașlahah al-Mursalah}

Pengertian yang memadai tentang kata mașlahah al-mursalah dalam pembahasan ini, didasarkan pada pendapat ulama ushul fikih. Abdul Wahhab Khallaf mendefinisikan mașlaḥah al-mursalah sebagai mașlaḥah dimana Syari' tidak mensyari'atkan hukum untuk mewujudkan mașlahah, juga tidak terdapat dalil yang menunjukkan atas pengakuannya atau pembatalannya. ${ }^{13}$ Sedangkan menurut Muhammad Abū Zahrah, menyatakan bahwa mașlaḥah al-mursalah adalah segala kemaslahatan yang sejalan dengan tujuan-tujuan Syari' (dalam mensyari'atkan hukum Islam) dan kepadanya tidak ada dalil khusus yang menunjuk tentang diakui atau tidaknya" 14

Definisi tentang mașlaḥah di atas jika dilihat dari segi redaksi nampak adanya perbedaan, tetapi jika dilihat dari segi isi pada hakikatnya ada satu kesamaan yang mendasar, yaitu menetapkan hukum dalam hal-hal yang sama sekali tidak disebutkan dalam al-Qur'an maupun al-Sunnah, dengan pertimbangan untuk kemaslahatan atau kepentingan hidup manusia yang bersendi pada asas menarik manfaat dan menghindari kerusakan.

\footnotetext{
${ }^{12} \mathrm{Al}-$ Shāțibī, al-I'tișām (Beirut, Libanon: Dār al-Fikr, 1991), h. 115-129.

${ }^{13}$ Abdul Wahhab Khallaf, ' Ilmu Uṣūl al-Fiqh (Jakarta: al-Majlis al-A'lāal-Indonesia, 1972), h. 84.

${ }^{14}$ Muhammad Abū Zahrah, 'Ilm al-Ușūl al-Fiqh (Beirut, Libanon: Dār al-Fikral-'Arabī, 1987), h. 279.
} 
Amin Farih

Lebih lanjut secara spesifik pengertian dan ruang lingkup berlakunya metode mașlahah al-mursalah ini telah dibahas oleh Dr. Jalāluddin 'Abd alRaḥmān dalam bukunya al-mașlahah al-mursalah wa makānatuhā fi al-tashrī' diantaranya menyatakan:

$$
\begin{aligned}
& \text { المصلحة وردت فى لغة العرب بمعنى: الاعمال الباعثة على نفع الانسان: فالمصلحة } \\
& \text { واحدة ـ المصالح ـ الصلاح _ وهي ضد المفسدة يقال أصلح ایى أتى بالصلاح وهو } \\
& \text { الخير والصواب ......... لكن ما اردناه بالمصلحة هنا, المحافظة على مقصود الشرع من } \\
& \text { المصالح النافعة, التى وضعها وحدد حدودها, لا على مقتضى أهواء الناس وشهواتهم. }
\end{aligned}
$$

"Mașlahah yang berlaku dikalangan ahli bahasa Arab yaitu setiap perbuatan yang bisa mendatangkan kemanfaatan bagi manusia, kata mașlaḥah adalah bentuk tunggal dari kata mașālih yang berarti setiap kebaikan (kepentingan hidup manusia) lawan dari kerusakan. Dikatakan baik jika dapat mendatangkan kemanfaatan/kemaslahatan yakni hal-hal yang baik dan yang benar..... Akan tetapi yang dimaksud kemaslahatan disini adalah memelihara tujuantujuan syari'at dari kemaslahatan yang bermanfaat, begitu juga yang dibatasi dengan beberapa batasan dan tidak diterapkan pada hal-hal yang ditimbulkan oleh hawa nafsu manusia dan keinginan keinginannya saja“15

Kata maṣlaḥah menurut Jalāluddin 'Abd al-Raḥmān diartikan dengan melepaskan atau lepas dari pertimbangan Syari'.16 Jadi mașlahah al-mursalah menurut beliau adalah sesuatu yang sunyi dari semacam dalil, tetapi dalam suatu waktu, hal tersebut sesuai dengan ibarat-ibarat Syari' secara keseluruhan baik tujuan-tujuan atau hukumnya"17

\section{Kemaslahatan sebagai Metode Istinbāț Hukum Islam menurut Imam al- Shāțibī}

Islam sebagai agama "hanïf" dengan berbagai metode dan sumber ajarannya selalu bertujuan untuk mengatasi berbagai masalah yang berkembang di masyarakat. Ijtihad yang diklaim sebagai salah satu metode pencarian alter-

15Jalāl al-Dīn 'Abd al-Raḥmān, al-Mașāliḥ al-Mursalah wa Makānatuhā fi al-Tashrī’ (Mațba'ah alSa'ādah, 1983), h. 12.

16Ibid., h. 15.

17 Ibid., h. 16.

50 || Volume 25, Nomor 1, April 2015

AL-AHKAM — ISSN 0854-4603 
natif terhadap dinamika dan problematika kehidupan yang berkembang di masyarakat, memberikan solusi yang dinamis sesuai dengan kaidah hukum yang berlaku tanpa meninggalkan zamannya, sekaligus sebagai interpretasi terhadap naș (al-Qur'an dan Hadis) yang sifatnya global dan tidak diterangkan secara rinci dan detail.

Ijtihad sebagai sumber ketiga setelah al-Qur'an dan Hadis, mempunyai objek segala sesuatu yang tidak diatur secara rinci dalam naș, serta terhadap masalahmasalah yang sama sekali tidak mempunyai landasan yang jelas dalam naș. Ijtihad merupakan metode hukum yang memberikan kemudahan bagi orang yang mengalami jalan buntu dalam mencari sumber asli dan kesusahan dalam mengatasi problem-problem yang berkaitan dengan kehidupan manusia terutama dalam masalah hukum, karena Islam sendiri mengizinkan manusia melampaui naș hukum yang global dan tidak diterangkan secara rinci. Namun demikian mereka harus mengetahui kaidah-kaidahnya dan sekaligus bertanggung jawab kepada Allah jika ia bertindak kurang cermat.18

Dalam perkembangannya ijtihad mempunyai banyak corak penalaran. Diantaranya yang terkenal adalah corak penalaran istiṣlāḥi. Corak penalaran istișlāhị adalah upaya penggalian hukum yang bertumpu pada prinsip-prinsip kemaslahatan yang disimpulkan dari al-Qur'an dan Hadis. Adapun kemaslahatan yang dimaksud disini adalah semua kemaslahatan yang secara umum ditunjuk oleh kedua sumber hukum Islam, artinya kemaslahatan itu tidak dapat dikembalikan kepada ayat al-Qur'an atau Hadis secara langsung, melainkan melalui prinsip-prinsip umum kemaslahatan yang dikandung dalam naș alQur'an dan Hadis. Dalam perkembangan pemikiran ushul fikih, metode ini dikenal dengan metode mașlahah mursalah. ${ }^{19}$

Menurut pandangan al-Shāțibī, mașlaḥah mursalah dapat digunakan sebagai metode legislasi hukum Islam. Ini berdasarkan pada interpretasi ayatayat dalam al-Qur'an, bahwa tujuan disyari'atkannya Islam diantaranya adalah untuk menjaga kemaslahatan manusia secara menyeluruh guna memenuhi kebutuhan hidupnya. Hal ini sesuai firman Allah:

\footnotetext{
18Muhammad Muslihuddin, Filsafat Hukum Islam dan Pemikiran Orientalis, Studi Perbandingan Sistem Hukum Islam (Yogyakarta: Tiara Wacana, 1997), h. 134.

${ }^{19}$ Muhammad Abū Zahrah, Ușūl al-Fiqh (Beirut, Libanon: Dār al-Fikr, 1958), h. 277-278.
} 
Amin Farih

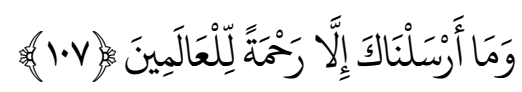

"Dan tidaklah Kami mengutus kamu kecuali untuk menjadi rahmat bagi semesta alam."20

Demikian juga dalam surat Yūnus: 57:

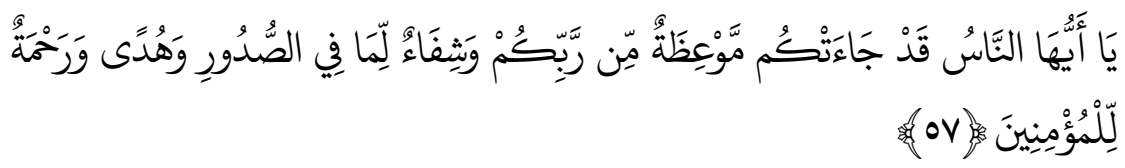

"Wahai manusia, sesungguhnya telah datang kepadamu pelajaran dari Tuhanmu dan penyembuh bagi penyakit-penyakit (yang berbeda) dalam dada dan hidayah serta rahmat bagi orang-orang mu'min.21

Syari'ah sangat melindungi kemaslahatan yang begitu luas. Oleh karenanya, menurut al-Shāțibī, perlu adanya pembatasan yang jelas terhadap mașlahah guna menghindari penafsiran yang bias terhadap mașlahah dari bid'ah dan penafsiran yang tidak sesuai naș. Menurut al-Shāțibī, pembatasan itu terbagi dalam tiga unsur, yang juga merupakan faktor yang sangat terkait dalam pembentukan sebuah hukum:

\section{Mașlahah yang Legalitasnya Berdasar pada al-Qur'an dan Hadis}

Menurut al-Qur'an dan Hadis, bila terdapat suatu illat yang mengandung suatu kemaslahatan secara jelas, maka kemaslahatan tersebut disebut almașlahah al-mu'tabarah.22 Seperti pemeliharaan jiwa, merupakan kemaslahatan yang perlu diwujudkan. Keharusan perwujudan ini diterangkan secara jelas dalam al-Qur'an surat al-Baqarah ayat 178 tentang pelaksanaan hukum qișās. Demikian juga pemeliharaan terhadap harta. Al-Qur'an dalam surat al-Mā'idah ayat 38 mengancam terhadap pencuri yang senantiasa mengambil harta orang lain. Larangan Allah mendekati berzina (artinya menjaga terhadap keturunan) dalam surat al-Isrā' ayat 32 merupakan usaha untuk mewujudkan kemaslahatan terhadap keturunan dan kehormatan manusia.

\footnotetext{
${ }^{20}$ QS. al-Anbiyā': 107.

21QS. Yūnus: 57.

${ }^{22} \mathrm{Al}-$ Shāțibī, al-I'tișām, h. 113. Lihat juga, Husayn Hamid Hasan, Naẓariyat al-Mașlaḥah fi ' l-Fiqh alIslāmī (Beirut: Dār al-Fikr, 1971), h. 15.
}

52 || Volume 25, Nomor 1, April 2015

AL-AHKAM — ISSN 0854-4603 
Dalam transaksi ekonomi misalnya, dianjurkan adanya kesaksian yang adil, merupakan usaha untuk mewujudkan bentuk-bentuk muamalah dan mekanisme niaga yang jujur dan membawa kemaslahatan bagi kedua belah pihak, dan masih banyak lagi tentang kemaslahatan "mu'tabarah" yang secara jelas diterangkan dalam naș.

\section{Mașlaḥah yang Ditolak Legislasinya oleh al-Qur'an dan Hadis}

Ada suatu kemaslahatan yang dalam kebiasaan manusia itu merupakan suatu mașlahah yang perlu dilindungi, namun oleh Syari' hal itu tidak dibenarkan karena bertentangan dengan isi dan ajaran naș secara mendasar. ${ }^{23}$ Contohnya adalah fatwa dari seorang ulama ternama yaitu imam al-Laits kepada seorang Raja di kerajaan Andalus yang melakukan jima' (persetubuhan) dengan istrinya pada siang hari di bulan Ramadhan. Hukum yang diterapkan oleh Imam al-Laits adalah bahwa Raja dianjurkan untuk melakukan puasa berturut-turut selama dua bulan, sebagai ganti dari kewajiban Raja untuk memerdekakan budak. Imam al-Laits berpendapat demikian dengan pertimbangan bahwa hukuman memerdekakan budak bagi seorang Raja merupakan hal yang ringan dan sanksi tersebut tidak berdampak positif, sehingga dimungkinkan Raja tersebut akan mengulangi lagi kesalahannya, karena sanksinya terlalu ringan menurut Raja tersebut. Menurut imam al-Laits cara untuk meredam perbuatan Raja tersebut adalah dengan cara memberi sanksi yang lebih berat yaitu dengan puasa dua bulan berturut-turut, walaupun sanksi puasa ini dalam ketentuan naș merupakan urutan kedua setelah memerdekakan budak (sebagai urutan sanksi pertama). Hal tersebut juga dipandang lebih mempunyai kemaslahatan hukum. Kemaslahatan seperti yang diterangkan oleh imam al-Laits di atas, merupakan kemaslahatan yang tidak mendapat legislasi dari al-Qur'an, karena kemaslahatan tersebut sangat bertentangan dengan ketentuan urutan sanksi dalam naș.

Menurut Jumhur ulama dan cendekiawan Muslim, seperti Yūsuf alQarḍawī, bahwa pendapat imam al-Laits itu hanya melihat kepada mașlaḥah untuk diri Raja, tetapi melupakan mașlahah yang lebih penting dan lebih besar yaitu mașlahah para budak yang perlu dimerdekakan dan dibebaskan dan keluar dari perbudakan yang dianggap oleh syara' sebagai kematian. Untuk itulah al-Qur'an dan Hadis menganggap "perbuatan memerdekakan budak"

23Ibid., h. 114. Lihat: Wahbah al-Zuhaylī, Ușūl al-Fiqh al-Islāmī (Beirut: Dār al-Fikr, 1995), h. 770-771. 
Amin Farih

sebagai ibadah paling besar untuk mendekatkan diri kepada Allah.24 Kemaslahatan di atas termasuk kategori "mașlahah mulghah".

\section{Mașlaḥah yang tidak Terdapat Legalitas Naș, baik terhadap Keberlakuan maupun Ketidakberlakuannya}

Mașlahah yang tidak ditunjuk oleh naș baik dalam tingkat naw' (macam) maupun pada tingkat jins (jenis) yang tidak mendapatkan legalitas khusus dari naș tentang keberlakuan dan ketidakberlakuannya disebut mașlahah mursalah. Mursalah artinya lepas dari tunjukan naș secara khusus. Terhadap mașlahah mursalah ini al-Shātịī membagi dalam dua katagori, yaitu: Pertama, kemaslahatan yang tidak diakui oleh Syari' karena secara mendasar kemaslahatan tersebut bertentangan dengan ajaran al-Qur'an dan Hadis. Contohnya adalah pembunuhan dengan maksud agar mendapatkan warisan. Menurut Syari' si pembunuh tersebut tidak akan mendapatkan bagian waris dari si mayit, karena tindakan tersebut bertentangan dengan illat yang ada dalam naș, walaupun tujuannya adalah untuk mendapat suatu mașlahah (yaitu pembagian harta). ${ }^{25}$

Kedua, Suatu kemaslahatan yang ada relevansinya dengan tujuan syar'i. Dalam hal ini al-Shāțibī mencontohkan sepuluh kemaslahatan yang dibenarkan oleh syar'i karena berdasar pada mașlahah mursalah yaitu: 1) Pengumpulan dan pengkodifikasian mushaf; 2) Ketentuan sanksi 80 kali jera terhadap peminum minuman keras (khamr); 3) Adanya jaminan terhadap barang yang dijual atau barang yang diperbaiki atau barang pesanan, bila penjual atau penawar jasa tidak menepati kesepakatan sesuai akad yang ditetapkan. 4) Pemberian maaf terhadap penawar jasa/pemborong bila ia melakukan penyelewengan. 5) Kebijaksanaan dan keadilan Imam sebagai landasan serta pijakan hukum; 6) Tidak dibolehkannya sanksi pidana dengan bentuk berupa uang; 7) Menempati tempat haram dan memakan barang haram karena dalam keadaan darurat; 8) Penerapan qiṣās terhadap golongan (kelompok manusia) yang melakukan pembunuhan seperti penerapan qișās pembunuhan yang dilakukan oleh manusia satu (tunggal); 9) Hakim dan Mufti dari seorang yang belum mencapai derajat mujtahid; 10) Menunjuk Imam

\footnotetext{
${ }^{24}$ Yūsuf Qarḍawī, Ijtihad dalam Syari'at Islam, terj.: al-Ijtihād fi al-Sharī'ah al-Islām, Alih Bahasa: Drs. Ahmad Syathori (Jakarta: Bulan Bintang, 1897), h. 225.

${ }^{25}$ Al-Shātịī, al-I'tișām, h. 115.
} 
yang lebih memenuhi syarat lebih baik, dari pada Imam yang tidak mampu (tidak memenuhi syarat). ${ }^{26}$

\section{Maqāṣid al-Sharīah dan Mașlahah Menurut Imam al-Shāțibī}

\section{Eksistensi Maqāṣid al-Sharīah menurut al-Shāțibī}

Al-Shātịī meletakkan maqāșid al-sharīah atau tujuan-tujuan hukum Islam sebagai landasan doktrinnya. Doktrin ini merupakan pengembangan dari konsep mașlahah sebagaimana dikembangkan pada masa pra-Syafi'i dalam kontemplasi-kontemplasinya tentang hukum. Al-Shātibī sampai pada kesimpulan bahwa kesatuan hukum Islam berarti kesatuan dalam asal-muasalnya, tetapi lebih-lebih lagi dalam maksudnya. Dalam rangka menegakkan yang belakangan ini, Shāțibī mengembangkan doktrin maqāșid al-sharīah dengan menjelaskan bahwa tujuan akhir hukum adalah satu, yaitu mașlahah atau kebaikan dan kesejahteraanumat manusia.

Kendatipun demikian, tesis Shāțibī ini menyentuh beberapa isu teologis di mana sejumlah kaum Asy'arian akan tidak sependapat dengannya. Sebagai konsekuensinya, Shāțibī terlebih dahulu melangkah untuk menegakkan tesisnya ini. Sebagai pendahuluan untuk menjelaskan doktrin maqūșid al-sharīah, Shāțibī mempertahankan bahwa doktrin ini berdasarkan pada premis yang biasa diterima yang bersifat teologis dalam asal-muasalnya. Premis itu ialah bahwa Allah melembagakan syari'ah (hukum-hukum) demi mașāliḥ (kebaikan) manusia, baik jangka pendek maupun jangka panjang.

Doktrin maqāṣid al-sharīah imam al-Shāțibī merupakan suatu usaha untuk menegakkan mașlahah sebagai unsur esensial bagi tujuan-tujuan hukum Islam. Di dalamnya dibicarakan problem relativitas mașlahah serta hubungan mașlahah dengan taklîf secara cukup rinci. Al-Shātibī juga berusaha untuk memfalsifikasi implikasi-implikasi determinisme teologis dan dilema relativitas mașlaḥah dengan mengusulkan untuk mempelajari problem ini dalam dua tingkat. Pada tingkat pertama, Ia mendiskusikan maqāṣid al-sharīah dan pada

${ }^{26} \mathrm{Al}$-Shātịīī, al-I'tisām, h. 115-126. 
Amin Farih

tingkat kedua ia membicarakan maqāṣid mukallaf (subjek hukum) ${ }^{27}$. Dengan mengusulkan bahwa mașlahah merupakan tujuan Syari' pada tingkat yang pertama, maka Ia mengusulkan bahwa legislatorlah yang memutuskan apa mașlaḥah itu. Demikian pula, al-Shāṭibī menekankan bahwa diskusi ini bukan hasil final, yang karenanya masih terbuka bagi diskusi selanjutnya. Akan tetapi tujuan mukallaf yang juga mencakup legislator, jika dan selama ia adalah mukallaf, merupakan ketaatan kepada tujuan hukum.

Skema diskusi yang dilakukan imam al-Shāțibī atas maqāṣid al-sharīah adalah sebagai berikut: 1) Qașd al-Shāri' (maksud legislator), meliputi empat aspek: Pertama, intensi primer dari Syari' dalam melembagakan hukum tertentu; Kedua, intensi Syari' dalam melembagakan hukum agar bisa dipahami (ifhām); Ketiga, intensi Syari' dalam melembagakan hukum itu untuk menuntut taklif; Keempat, intensi Syari' dalam memasukkan mukallaf di bawah perintah hukum itu. 2) Qașd al-Mukallaf (maksud mukallaf), meliputi tiga aspek; Pertama, membicarakan pengertian mașlahah, tingkatan, karakteristik, dan relativitas atau keabsolutannya. Kedua, mendiskusikan dimensi linguistik dari problem taklif yang diabaikan oleh juris-juris lain. Suatu perintah yang merupakan taklif harus bisa dipahami oleh semua subjeknya, tidak saja dalam kata-kata dan kalimat tetapi juga dalam pengertian pemahaman linguistik dan kultural. Imam Shāțibī mendiskusikan problem ini dengan cara menjelaskan dua istilah, yaitu: al-dalālah al-așliyyah (pengertian yang esensial) dan aldalālah al-'umūmiyyah (bisa dipahami oleh orang awam); Ketiga, menganalisis pengertian taklif dalam hubungannya dengan qudrah (kemampuan), mashaqqah (kesulitan) dan lain-lain. 28

\section{Eksistensi Mașlaḥah Menurutal-Shāțibī}

Tujuan utama dari Sharī’ adalah mașlahah manusia. Kewajiban-kewajiban dalam syari'ah adalah memperhatikan maqāșid al-sharī'ah di mana ia merubah tujuan untuk melindungi mașālị̣ manusia. Jadi, maqāṣid dan mașlahah

\footnotetext{
${ }^{27} \mathrm{Al}$-Shāțibī, al-muwāfaqāt fi Ușūl al-Sharī'ah (Beirut, Libanon: Dār al-Fikr, t.th.), h. 24. Lihat juga: 'Abd al-Ḥamīd al-Abadī, al-Mujmal fí 'l-Tārīkh Andalūs (Kuwait: Dār al-Qalam, 1964), h. 76.

${ }^{28}$ Asafri Jaya Bakri, Konsep Maqashid Syari'ah Menurut al-Shātibī (Jakarta: Raja Grafindo Persada Press, 1996), h. 17. Lihat juga: Muḥammad ibn 'Alī ibn Muḥammad al-Shawkānī, aI-Qawl al-Mufíd fi Adillat al-Ijtihād wa ' '-Taqlīd, cet. 1 (Kuwait: Dār al-Qalam, 13960, h. 90.
} 
menjadi istilah yang bisa saling ditukar dalam kaitan dengan kewajiban dalam diskusi imam al-Shāțibī tentang mașlaḥah. Shāțibī mendefinisikan mașlaḥah sebagai berikut: "Yang saya maksud dengan mașlaḥah di sini adalah mașlaḥah yang membicarakan substansi kehidupan manusia, dan pencapaian apa yang dituntut oleh kualitas-kualitas emosional dan intelektualnya, dalam pengertian yang mutlak."29 Ini adalah pengertian mașlahah dalam pengertiannya yang mutlak. Tetapi al-Shātibī mempertimbangkan berbagai pengertian lain di mana mașlahah bisa dipelajari dan mașālị̣ demi kepentingan dunia maupun akhirat bisa dilihat sebagai suatu sistem yang memiliki berbagai tingkatan.

Unsur kedua dalam pengertian mașlaḥah adalah pengertian "melindungi kepentingan-kepentingan”. Al-Shātịī menjelaskan bahwa syari'ah membicarakan perlindungan terhadap mașāliḥ, baik dalam suatu cara yang negatif karena untuk memelihara eksistensi mașālih, syari'ah mengambil ukuranukuran untuk mendukung landasan-landasan mașālih itu, atau dalam suatu cara yang negatif untuk mencegah kepunahan mașālị̣ ia mengambil ukuranukuran untuk menghilangkan unsur apapun yang secara aktual atau potensial merusak mașālih.

Al-Shātịī membagi maqāṣid dan mașāliḥ menjadi ḍarūrī (keharusan), hājīi (dibutuhkan) dan taḥsin̄ī (penghias). Maqāșid darūri disebut harus (necessary) karena maqāșid ini tidak bisa dihindarkan dalam menopang mașāliḥ al-ddīn (agama dan akhirat) dari dunia, dalam pengertian bahwa jika mașālih ini dirusak maka stabilitas mașālih dunia pun rusak. Kerusakan mașālih ini berakibat berakhirnya kehidupan di dunia ini, dan di akhirat ia mengakibatkan hilangnya keselamatan dan rahmat. ${ }^{30}$

Ibadat bertujuan untuk melindungi agama. Contoh-contoh dari ibadat adalah keyakinan dan pernyataan iman (keesaan Allah dan kerasulan Muhammad) shalat, zakat, puasa, dan haji. Adat bertujuan melindungi nafs (jiwa) dan akal. Mencari makanan, minuman, pakaian dan perlindungan adalah contoh-contoh tentang adat. Muamalat juga melindungi nafs dan akal. Imam al-Shātibī mendefinisikan jināyat sebagai hukum-hukum yang memperhatikan kelima

${ }^{29} \mathrm{Al}$-Shātịī, al-I'tiṣām, hal. 91. Lihat juga: al-Shātịīi, al-Muwāfaqāt, h. 27.

${ }^{30} \mathrm{Al}$-Shāțibī, al-I'tișām, juz II, h. 217. Lihat Juga: al-Ghazalī, al-Mustasfāa (Beirut, Lebanon: Dār alFikr, tth), h. 139-140. Juga Wahbah al-Zuhailī, Ușūl al-Fiqh al-Islām (Beirut, Lebanon: Dār al-Fikr, 1995), h. 812. 
mașālih di atas dalam cara preventif, jinayat menentukan pembersihan apa yang menghalangi realisasi kepentingan-kepentingan ini. Untuk mengilustrasikan jinayat, ia memberikan contoh tentang qișās (hukum balas setimpal) dan diyat (uang tebusan darah) bagi jiwa, dan hadd (hukuman karena meneguk minuman keras) untuk melindungi akal.

Hajïyyah disebut karena dibutuhkan untuk memperluas (tawassu') tujuan maqāșid dan untuk menghilangkan kekakuan pengertian-literal, karena penerapan hukum-hukum itu menggiring ke dalam kesulitan dan akhirnya menghancurkan maqāșid. Jadi, jika hājïyyah tidak dipertimbangkan bersama darūriyyah maka manusia secara keseluruhan akan menghadapi kesulitan. Kendatipun demikian, hancurnya hājiyyah tidak berarti hancurnya keseluruhan mașāliḥ, seperti yang ada dalam ḍarūriyyah. Contoh-contoh hājiyyah adalah sebuah bentuk dalam ibadat, yaitu rukhșah (keringanan) dalam shalat dan puasa diberikan karena sakit atau bepergian yang jika tidak diberikan mungkin akan menyebabkan kesulitan dalam shalat, puasa dan lain-lain.

Tahsinniyyah berarti mengambil apa yang sesuai dengan apa yang terbaik dari kebiasaan-kebiasaan (adat) dan menghindari cara-cara yang tidak disukai oleh orang-orang bijak. Tipe mașāilh ini mencakup kebiasaan-kebiasaan terpuji (etik, moralitas). Contoh tipe ini adalah sebagai berikut: Dalam masalah ibadat adalah kesucian (tahārah) atau kesopanan dalam menutup bagianbagian tubuh tertentu (awrat) dalam shalat. Dalam masalah adat adalah etika, sopan santun dan lain-lain. Dalam masalah muamalat adalah larangan menjual barang-barang atau makanan dan minuman yang najis dan menempatkan seorang budak sebagai saksi dan pemimpin. Dalam masalah jināyat adalah larangan membunuh seorang yang merdeka sebagai ganti seorang budak. 31

Imam al-Shāṭibī menganggap pembagian mașālị̣ di atas sebagai suatu struktur yang terdiri atas tiga tingkatan yang satu sama lain saling berhubungan. Hubungan antara dua aspek dari hubungan ketiganya tersebut sebagai berikut. Pertama, setiap tingkatan secara terpisah menuntut penggabungan unsur tertentu yang melengkapi tingkatan ini. Kedua, masingmasing terkait dengan yang lain. Masing-masing dari ketiga tingkatan ini

\footnotetext{
31Al-Shātịī, al-I'tișām, juz I, h. 317. Lihat juga: Albert Hourani, Arabic Thought in The Liberal Age, 1798-1939 (London: Oxford, 1962), h. 65.
} 
menuntut unsur-unsur tertentu untuk mencapai realisasi penuh atas tujuantujuannya. Misalnya, qișās (hukum balasan sama) tidak bisa diwujudkan tanpa suatu persyaratan tamattul (evaluasi paralel).

Namun demikian, posisi ini membutuhkan dua klasifikasi. Pertama, kekurangan unsur-unsur pelengkap ini tidak sama dengan peniadaan tujuantujuan yang esensial, Kedua, pertimbangan dan realisasi unsur-unsur pelengkap harus tidak mengakibatkan penegasian tujuan-tujuan orisinal, yakni, jika pertimbangan atas suatu unsur pelengkap mengakibatkan hilangnya tujuan orisinal, maka pertimbangannya tidak akan valid. Alasan-alasan bagi persyaratan ini adalah karena unsur pelengkap adalah seperti suatu kualitas (sifat). Jika pertimbangan atas suatu kualitas mengakibatkan penegasian objek yang disifati (mawșūf) maka kualifikasi ini juga dinegasikan. Alasan yang lain, seolah-olah dianggap bahwa pertimbangan atas unsur pelengkap mengakibatkan perwujudan kepentingan-kepentingannya dengan mengorbankan tujuan orisinal, maka ditekankan bahwa realisasi atas (tujuan) orisinal ini disukai.

Hubungan satu sama lain, dari tiga tingkatan mașālih di atas adalah sama dengan hubungan mașālih pelengkap dengan tujuan orisinal hukum. Jadi, tahsiniyyah merupakan unsur pelengkap bagi hājïyyah, dan tahsiniyyah merupakan bagian fundamental dari mașālih. Mengingat penjelasan di atas, imam al-Shātibī mendeduksi lima ketentuan berikut mengenai hubungan ini: 1) Ḍarūrī merupakan basis bagi segala mașāliḥ; 2) Ikhtilāl (kerusakan) ḍaruri mengharuskan ikhtilāl mașālị̣ lain secara mutlak; 3) Kendatipun demikian, ikhtilāl mașālih tidak harus berarti ikhtilāl yang ada di dalam darūrī itu sendari; 4) Dalam kasus tertentu, ikhtilāl tahsininyyah atau häjïyyah mutlak berarti ikhtilal darūrī; 5) Perlindungan (muḥăfazah) atas taḥsinniyyah dan hạjizyyah merupakan keharusan untuk mencari ḍarūrī. ${ }^{32}$

Ketentuan-ketentuan ini bisa diilustrasikan melalui hukum qișās. Hukum Qișās merupakan ḍarūrī, sedangkan tamațtul (pertimbangan kesamaan) dalam qișās adalah taḥsinì dan takmïlì. Untuk mengilustrasikan ketentuan pertama, tamațtul (taḥsinī) adalah unsur pelengkap dan ada hanya dikarenakan oleh qișās (ḍarūrī). Jadi, suatu mașlaḥah ḍarūrī (qișās) merupakan basis bagi suatu

\footnotetext{
32Lihat: al-Shāṭibī, al-Muwāfaqāt, juz II, h. 193-225. Lihat juga: Muștafā Zayd, al-Maṣlaḥah fi alTashrī’al-Islām wa Najm al-Dīn al-Ṭüfi (Kairo: Dār al-Fikr al-'Arabī, 1954), h. 124.
} 
Amin Farih

mașlaḥah taḥīnī (tamațul). Untuk mengilusirasikan ketentuan kedua, jika tidak ada qiṣās, maka tidak ada pertimbangan bagi tamațtul. Dengan kata lain, ikhtilāl (kerusakan) ḍrūrī berarti harus sama bagi tingkatan-tingkatan mașāliḥ lainnya. Untuk mengilustrasikan ketentuan ketiga, ikhtilāl tamattul tidak menuntut ikhtilāl qișās. Ketentuan keempat dan kelima bisa diapresiasi jika seseorang menangkap pengertian di mana ḍarūrī dipengaruhi oleh ikhtilāl mașāliḥ lainnya.

Imam al-Shāṭibī menjelaskan pengaruh mașāliḥ lain atas mașālị̣ darūrī dengan empat kesamaan berikut: 1) Hubungan mașālih lain dengan mașālih ḍarūrī adalah seperti hubungan zona-zona protektif (himā). Ikhtitāl salah satu zona protektif sama dengan ikhtilāl zona selanjutnya dan akhimya sama dengan ikhtilāl mașālih ḍarūrī yang berada di tengah zona-zona ini. 2) Hubungan ini juga bisa dipahami sebagai hubungan bagian dengan keseluruhan. Ikhtilāl bagianbagian jelas berarti sama dengan ikhtilāl keseluruhan. 3) Hājïyyah dan tahsiniyyah bisa dipahami sebagai individu-individu dalam hubungannya dengan yang universal, yakni ḍarüriyyah. 4) Hājìyyah dan tahsiniyyyah melayani mașālih ḍarūrī sebagai pendahuluan (muqaddimah), atau sebagai inter-relasi (muqārin). ${ }^{33}$

Sebagaimana disebutkan di atas, mașāliḥ juga dibagi menjadi mașālị̣ duniawi dan mașāliḥ ukhrawi. Mașāliḥ duniawi diukur dari dua sisi, yaitu: sisi pertama adalah memandang mașāliḥ itu sebagaimana ia benar-benar ada, dan sisi kedua adalah memandangnya berdasarkan pernyataan syari'ah. Mașāliḥ duniawi sebagaimana ia ada di dunia ini tidak ditemukan sebagai mașāliḥ murni. Agaknya ia bercampur dengan kondisi yang tidak menyenangkan dan kesulitan, betapapun besar atau kecil, dan mungkin mendahului, bersamaan atau mengikutinya. Demikian juga keadaannya sama dengan mafāsid (lawan mașālih) yang juga tidak murni tetapi ditemukan bercampur dengan kemudahan dan kesenangan tertentu. Kesesuaian fenomena di dunia ini menunjukkan fakta bahwa dunia ini diciptakan dari kombinasi berbagai hal yang berlawanan dan tidak mungkin untuk istikhlās hanya satu sisi saja. Karena alasan inilah maka mașāliḥ dan mafāsid di dunia ini diketahui hanya berdasarkan sisi yang menonjol. Jika sisi mașāliḥ dominan, maka masalah yang di-

\footnotetext{
${ }^{33}$ Al-Shātịibi, al-Muwāfaqāt, Juz II, h. 268. Lihat juga: Mușțafā al-Salabī, Ta'līl al-Ahkām Arḍ wa Tahlīl li Ṭarīqātal-Ta'līl wa Tațawwuratuhū fi 'Ușūr al-Ijtihād wa '-Taqlìd (Kairo:Azhar, 1949), h. 278-384.
} 
bicarakan biasanya dianggap sebagai suatu mașlahah, sebaliknya juga dengan mafșadah. Jadi, dalam masalah ini faktor yang dominan adalah adat. Harus dicatat di sini bahwa prinsip ini diterapkan hanya kepada perbuatanperbuatan yang berkaitan dengan adat, dan hanya kepada penentuan mașlahah atau mafșadah di dunia ini dengan cara mengetahuinya sebagaimana ia ada. Perbuatan-perbuatan yang bukan adat tidak dipengaruhi oleh prinsip ini.

Pendekatan kedua untuk mempertimbangkan mașāliḥ dunia ini adalah melihatnya dalam kaitannya dengan pernyataan (khițāb) syari'ah. Ketentuan dasar dalam pendekatan ini adalah bahwa mașālị̣ atau mafāsid sebagaimana dipertimbangkan oleh syari' adalah murni. Jika ia diharuskan bercampur (dengan sesuatu yang lain) maka ia tidak demikian dalam realitas syar'i. Sebagaimana dijelaskan di atas, mașlaḥah atau mafșadah di dunia ini, ditentukan oleh sisi yang dominan (al-jihat al-ghalïbah) dari suatu mașlahahah. Bagian yang dominanlah yang merupakan tujuan khițāb syar'i. Bagian yang didominasi (almaghlübah) baik mașlaḥah maupun mafșadah, bukanlah tujuan syar'i. Lantas mengapa unsur-unsur yang didominasi, kendatipun mungkin saja mașlaḥah, bukan tujuan syari'ah?. Di sisi lain bagaimana unsur-unsur ini bisa ada, ketika ia bukan merupakan tujuan syari'ah atau masih sebagai bagian dari mașlahah? Imam al-Shāțibī memecahkan kontradiksi mencolok ini dengan penjelasan sebagai berikut. Ia mempertahankan bahwa mașlahah al-maghlübah adalah mașlahah yang dianggap semacam itu menurut kebiasaan yang semata-mata dituntut (al-i'tiyādi al-kasbi) yakni tanpa menambahkan persyaratanpersyaratan syar'i bagi mașlaḥah. ${ }^{34}$ Biasanya, mașlaḥah semacam itu tidak dianggap mencari manfaat, bagian mașlahah yang bukan merupakan tujuan shar'iyyah (legalitas) dari hukum Islam sebagai suatu keseluruhan inilah yang dibicarakan.

Adapun yang terkait dengan mașlahah akhirat juga murni (seperti misalnya rahmat surga) di samping bercampur seperti hukuman neraka yang kadang-kadang juga diberikan bahkan kepada orang yang mengimani keesaan Allah. Ketentuan dasar mengenai mașālị atau mafāsid semacam itu ialah

\footnotetext{
${ }^{34} \mathrm{Al}$-Shāțibī, al-I'tișām, juz II, h. 275. Lihat juga: R. Paret, "Istihsan dan Istislah", dalam: Shorter Encyclopaedia of Islam (Leiden: Brill, 1961), h. 185. Lihat juga: Muhammad Bayrām, Șafwat al-I'tibār, vol. II, h. 11.
} 
bahwa semua ini ditentukan menurut syari'ah, karena akal tidak memiliki tempat dalam masalah-masalah yang berhubungan dengan akhirat. Kadangkadang kekacauan muncul dikarenakan mempertimbangkan mașālị̣ atau mafāsid murni karena bercampur diantara salah satunya. Misalnya, rahmat yang diberikan kepada para Nabi di surga berbeda dari rahmat yang diberikan kepada orang-orang lain. Mereka yang berada di tingkatan yang lebih rendah mungkin dianggap tengah dihukum dengan tidak diberi rahmat yang dianugerahkan kepada tingkatan-tingkatan yang lebih tinggi.

Dari penjelasan di atas, al-Shāțibī menyimpulkan ketentuan-ketentuan berikut sebagai karakter mașlaḥah: 1) Tujuan legislasi (tashri') adalah untuk menegakkan (iqāmah) mașālih di dunia ini dan di akhirat, dalam suatu cara di mana mașāliḥ ini merusak sistem syara'; 2) Syari' menghendaki mașāliḥ harus mutlak; 3) Alasan bagi kedua pertimbangan di atas ialah bahwa shari'ah telah dilembagakan harus abadi, universal (kull) dan umum ('âmm) dalam hubungannya dengan segala macam kewajiban (takālif), subjek hukum (mukallafin) dan kondisi-kondisinya. ${ }^{35}$

Ketiga karakter di atas menuntut mașālị harus mutlak dan universal. Kemutlakan berarti bahwa mașāliḥ tidak boleh subjektif dan relatif. Kenisbian biasanya didasarkan pada sikap menyamakan suatu mașlaḥah dengan salah satu kondisi sebagai ahwa al-nafs (kesenangan-kesenangan pribadi), manāfi' (keuntungan-keuntungan pribadi), nayl al-shahawāt (pemenuhan keinginankeinginan nafsu), dan aghräḍ (kepentingan-kepentingan individu).

Menurut al-Shāțibī semua pertimbangan di atas memberikan konsep mașlaḩah akan makna relatif dan subjektif, yang bukan merupakan pertimbangan Syari' dalam mașlahah, walaupun mungkin demikian dalam adat. la mengajukan argumentasi berdasarkan landasan-landasan sebagai berikut: Pertama, tujuan syari'ah adalah mengeluarkan mukallafin dari keinginan-keinginan suara hati nurani mereka untuk menjadikan mereka sebagai hamba Allah. Tujuan ini menegaskan sebuah pertimbangan kesenangan pribadi sebagai suatu unsur dalam mempertimbangkan mașlahah. Kedua, tidak bisa dianggap sebagai semata-mata manāfi' karena dalam adat maupun syara' mașālih bercampur

${ }^{35} \mathrm{Al}$-Shātịī, al-Muwāfaqāt, Juz IV, h. 146; Musțafā Zayd, al-Maṣlaḥah fíal-Tashrī'al-Islām, h. 47. 
dengan unsur-unsur negatif. Titik tekannya di sini ialah bahwa manāfi' bukanlah unsur esensial dalam pertimbangan mașāliḥ dalam adat maupun dalam syara'. Dalam adat, tujuan tertentu yang lebih tinggi seperti adanya kehidupan merupakan pertimbangan dasar dalam menentukan mașālih. Dalam syara' pertimbangan ini harus masih lebih tinggi dan yang demikian ini adalah dinamakan sebagai pertimbangan akhirat. Ketiga, pertimbangan memenuhi keinginankeinginan pribadi juga memberikan konsep mașlahah akan makna relatif yang lebih tinggi. Pertimbangan keinginan-keinginan pribadi berbeda dari satu ke lain keadaan, dari satu orang dengan orang lain dan dari satu waktu dengan waktu yang lain. Keinginan pribadi itu terlalu relatif sehingga tidak bisa menjadi suatu kriteria untuk menentukan mașlaḥah. Keempat, pertimbangan kepentingankepentingan pribadi menggiring tidak hanya ke dalam suatu divergensi tetapi lebih penting lagi juga ke dalam suatu konflik dengan orang-orang lain dan menghilangkan kepentingan-kepentingan orang lain. Sebagai konsekuensinya, relativitas dan subjektivitas disingkirkan dari pertimbangan syar'i atas mașlahah. Jadi ia harus mutlak. Dalam syara' kemutlakan ini diadakan oleh persyaratan bahwa mașlaḥah harus bertujuan mewujudkan kehidupan di dunia ini setarap dengan kehidupan di akhirat.

Karakter kedua dari mașlaḥah adalah bahwa mașlaḥah harus universal. 36 Universalitas ini tidak dipengaruhi oleh takhalluf (memperkecil) unsur-unsur partikularnya. Misalnya, hukuman-hukuman diberlakukan berdasarkan ketentuan universal bahwa biasanya hukuman-hukuman ini mencegah orang dari melakukan kejahatan. Kendatipun demikian, ada juga orang-orang tertentu yang walaupun dihukum, tidak menahan diri dari melakukan suatu kejahatan, tetapi pengecualian semacam itu tidak mempengaruhi validitas ketentuan umum tentang hukuman. Dalam shari'ah, al-ghälib al-akthar (mayoritas yang dominan) lah yang merupakan unsur definitif-umum (al'āmm al-qații) dalam pertimbangan suatu mașlaḥah. Ini merupakan karakter hal-hal universal induktif (al-kulliyyah al-istiqra'iyyah). Suatu ilustrasi tentang universal ini mungkin ditemukan dalam ketentuan-ketentuan universal dari

36Ibid., h. 265. Lihat juga: Fakhr al-Dīn al-Rāzī, al-Mahṣūl fi Ușūl al-Fiqh (MS. Yale University, Nemoy, A-1039 (L-643), h. 79. 
Amin Farih

suatu bahasa. Hal-hal universal dari suatu bahasa lebih dekat kepada hal-hal universal dari syari'ah, karena keduanya adalah wạ̣'i (dilembagakan, konvensional) tidak 'aqli (spekulatif). ${ }^{37}$

\section{Kesimpulan}

Menurut imam al-Shāṭib̄̄, prinsip-prinsip umum kemaslahatan yang dikandung dalam al-Qur'an dan Hadis semuanya bermuara pada doktrin maqāṣid al-sharīah yang tujuan utamanya adalah untuk menegakkan mașlahah sebagai unsur esensial bagi tujuan-tujuan hukum Islam. Maṣlaḥah mursalah menurut al-Shātịīi adalah suatu kemaslahatan yang tidak ditunjuk oleh nas alQur'an, baik dalam tingkat macam dan jenisnya dan tidak mendapatkan legalitas khusus dari naș al-Qur'an tentang keberlakuan dan ketidakberlakuannya. Mașlahah mursalah sebagai salah satu bagian dari metode ijtihad, dapat digunakan sebagai metode istinbāt hukum Islam, dengan syarat-syarat: Pertama, kemaslahatan tersebut merupakan penerjemahan terhadap semua kemaslahatan yang ada dalam al-Qur'an, sesuai yang ditentukan syari'at Islam; Kedua, kemaslahatan tersebut harus memperhatikan pemeliharaan aspek daruriyyah, hājiyyah dan tahsiniyyah; Ketiga, kemaslahatan tersebut hanya dapat diaplikasikan dalam bidang-bidang sosial kemasyarakatan (mu'amalah) yang tidak dijelaskan secara rinci dalam al-Qur'an.

Pemikiran al-Shāṭibī tentang mașlaḥah mursalah merupakan metode pemersatu dan alternatif terhadap perbedaan ulama tentang berlaku atau tidak berlakunya mașlahah mursalah sebagai metode istinbat hukum Islam. Konsep mașlaḥah mursalah menurut al-Shāțibì tidak dipandang sebagai metode istinbat hukum yang independen dan tidak berkaitan komponen ijtihad lain, melainkan sebuah metode istinbat yang sangat terkait dengan metode-metode ijtihad lainya, terutama terhadap tujuan-tujuan yang dikandung oleh syari'ah sebagai pangkal terbentuknya hukum Islam.[a]

\footnotetext{
${ }^{37}$ Al-Shāțibī, al-I'tișām, juz I, h. 119. Lihat juga: Abū Ḥasan al-Baṣrī, al-Mu'tamad fí Ușūl al-Fiqh , juz II (Damsyiq: al-Ma'had al-'Ilmī al-Firansī, 1964), h. 888.
} 


\section{DAFTAR PUSTAKA}

al-Abadī, 'Abd al-Hạīì, al-Mujmal fi al-Tārīkh Andalūs, Kuwait: Dār al-Qalam, 1964.

'Abd al-Raḥmān, Jalāl al-Dīn, al-Mașāliḥ al-Mursalah wa Makānatuhā fi alTashrï', Mațba'ah al-Sa'ādah, 1983.

Abdullah, M. Amin, Falsafah Kalam di Era Postmodernisme, Yogyakarta: Pustaka Pelajar, 1995.

Abū Zahrah, Muhammad, 'Ilm al-Ușūl al-Fiqh, Beirut, Libanon: Dār al-Fikr al'Arabī, 1987.

Abū Zahrah, Muḥammad, Ușūl al-Fïh, Beirut, Libanon: Dār al-Fikr, 1958.

Amin, Ahmad, Fajar al-Islam, cet. X, Kotabaru, Pinang, Singapura: Sulaiman Mar'iy, 1965.

Anas, Malik ibn, al-Muwatța', Beirut, Libanon: Dār al-Fikr, 1978.

Bakri, Asafri Jaya, Konsep Maqashid Syari'ah Menurut al-Shāțibī, Jakarta: Raja Grafindo Persada Press, 1996.

al-Bașrī, Abū Hasan, al-Mu'tamad fi Ușūl al-Fiqh, juz II, Damsyiq: al-Ma'had al'Ilmī al-Firansī, 1964.

al-Bukhārī, Abī 'Abdillah Muhammad ibn Ismā'īl, Șahịḥ al-Bukharī, Beirut, Libanon: Dār al-Kutub al-'Arabī, 1978.

Departemen Agama RI, al-Qur'an dan Terjemahannya, Jakarta: Yayasan Penyelenggara Penterjemah al-Qur'an: 1982.

al-Ghazālī, al-Mustașfā, Beirut, Lebanon: Dār al-Fikr, t.th.

Hasan, Ahmad, Pintu Ijtihad sebelum Tertutup, Bandung: Penerbit Pustaka, 1984.

Ḥasan, Husayn Ḥamid, Naẓariyat al-Mașlaḥah fi al-Fiqh al-Islāmī, Beirut: Dār alFikr, 1971.

Hourani, Albert, Arabic Thought in The Liberal Age, 1798-1939, London: Oxford, 1962.

al-Jawziyyah, Ibnu al-Qayyim, I'lām al-Muwaqqi'inn 'an Rabb al-'Ālamīn, Juz III, Mesir: Idārah Thibā'ah Mișriyyah, t.th.

Khallāf, 'Abd al-Wahhāb, 'Ilmu Ușūl al-Fiqh, Jakarta: al-Majlis al-A'lā alIndonesia, 1972. 
Amin Farih

Khallāf, 'Abd al-Wahhāb, Mașādir al-Tashrī' fi mā lā nașșa fihi, Beirut, Libanon: Dār al Fikr, 1972.

al-Khawlī, Bāhī, "Min Fiqh Umar fī al-Iqtiṣād wa 'l-Māl", dalam: Majalah alMuslimin, Vol. IV, Kairo: 1954.

al-Kurdi, Ahmad al-Hajj, al-Madkhal al-Fiqh: al-Qawā'id al-Kulliyah, Damsyiq: Dār al-Ma'ārif, 1980.

Mudzhar, Atho, Dr. HM., Membaca Gelombang Ijtihad: Antara Tradisi dan Liberasi, Yogyakarta, Titian Ilahi Press, 1998.

Muslihuddin, Muhammad, Filsafat Hukum Islam dan Pemikiran Orientalis, Studi Perbandingan Sistem Hukum Islam, Yogyakarta: PT. Tiara Wacana, 1997.

an-Na'im, Abdullahi Ahmed, Toward an Islamic Reformation: Civil Liberties, Human Rights and International Law, New York: Syracusse University Press, 1990.

Paret, R., "Istihsan dan Istislah", dalam: Shorter Encyclopaedia of Islam, Leiden: Brill, 1961.

Qardlawī, Yusuf, Ijtihad dalam Syari'at Islam, terj.: al-Ijtihād fi al-Sharī'ah alIslām, Alih Bahasa: Drs. Ahmad Syathori, Jakarta: Bulan Bintang, 1897.

al-Rāzī, Fakhr al-Dīn, al-Mahșūl fi Ușūl al-Fiqh, MS. Yale University, Nemoy, A1039 (L-643).

al-Salabī, Muștafā, Ta'līl al-Ahkām Arḍ wa Tahlīl li Tarīqāt al-Ta'līl wa Tațawwuratuhū fi 'Ușūr al-Ijtihād wa 'l-Taqlìd, Kairo: Azhar, 1949.

al- Shāțibī, al-I'tiṣām, Beirut, Libanon: Dār al-Fikr, 1991.

al-Shāțibī, al-muwāfaqāt fí Ușūl al-Sharī'ah, Beirut, Libanon: Dār al-Fikr, t.th.

al-Shawkānī, Muḥammad ibn 'Alī ibn Muḥammad, aI-Qawl al-Mufìd fi Adillat al-Ijtihād wa 'l-Taqlīd, cet. 1, Kuwait: Dār al-Qalam, t.th.

Wehr, Hans, a Dictionary of Modern Written Arabic, London: Mac Donald and Evans LTD, 1970.

al-Zuhaylī, Wahbah, Ușūl al-Fiqh al-Islāmī, Beirut: Dār al-Fikr, 1995.

Zayd, Mușțafā, al-Mașlahah fi al-Tashrī’ al-Islām wa Najm al-Dīn al-Ṭūfi, Kairo: Dār al-Fikr al-'Arabī, 1954.

66 || Volume 25, Nomor 1, April 2015

AL-AHKAM — ISSN 0854-4603 